
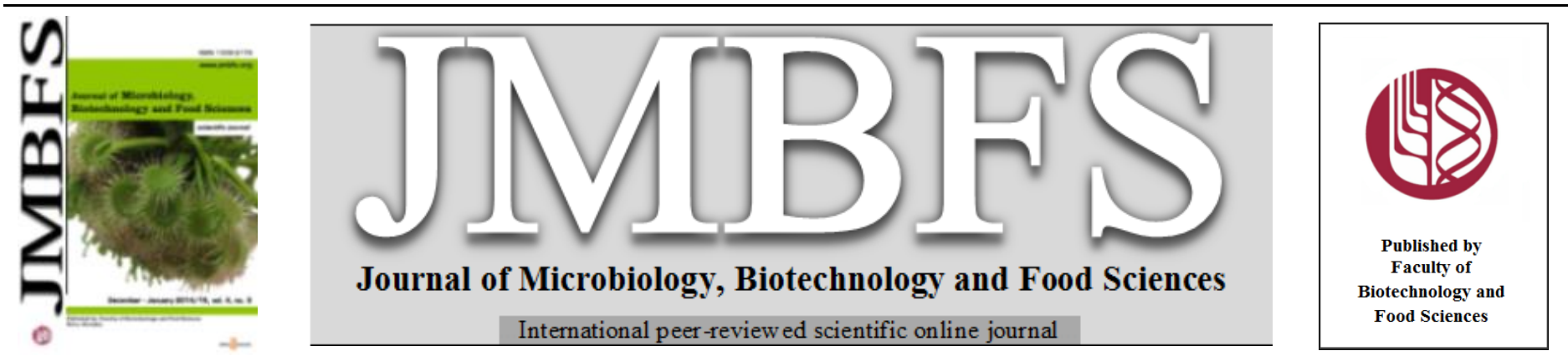

\title{
FACTORS INFLUENCING SYNTHESIS OF EXTRACELLULAR LIPASES BY YARROWIA LIPOLYTICA IN MEDIUM CONTAINING VEGETABLE OILS
}

\author{
Agata Urszula Fabiszewska*, Ewa Białecka-Florjańczyk
}

Address(es): PhD Agata Urszula Fabiszewska,

Warsaw University of Life Sciences, Faculty of Food Sciences, Department of Chemistry, Nowoursynowska Street 159c, 02-787, Warsaw, Poland, Phone number: (+ 48 22) 5937621 .

*Corresponding author: agata fabiszewska@sggw.pl

doi: 10.15414/jmbfs.2014-15.4.3.231-237

ARTICLE INFO

Received 7. 5. 2014

Revised 13. 7. 2014

Accepted 15. 10. 2014

Published 1. 12. 2014

Regular article

OPEN 2 ACCESS

\begin{abstract}
The aim of this study was to evaluate lipase activity of Yarrowia lipolytica KKP 379 in media containing selected vegetable oils as the sole carbon source. The highest activity for extracellular Yarrowia lipolytica lipases was obtained in a corn oil medium, which was almost two times higher compared to lipase activity in olive oil medium, while the lowest lipolytic activity was observed in medium containing rice and peanut oils. Literature suggested that free fatty acids, especially oleic acid present in olive oil, are good inducers of microbial lipase synthesis, however the results of this study do not support the hypothesis that high oleic acid content stimulates high lipolytic activity. Neither the relationship between the percentage of individual fatty acids in triacylglycerols of vegetable oils nor their content at the $s n-1,3$ positions influenced the activity of extracellular lipases synthesized by Yarrowia lipolytica KKP 379 . Several hypothesis are given regarding the presence of other factors which may determine differences in extracellular lipolytic activity of yeast grown on different vegetable oils, such as presence of metal ions, the content of free fatty acids and critical micellar concentration.
\end{abstract}

Keywords: Lipase, lipase activator, oleic acid, triacylglycerol structure, vegetable oil, Yarrowia lipolytica

\section{INTRODUCTION}

Yarrowia lipolytica is the only species within the genus Yarrowia, a commonlyoccurring yeast in nature and used in many industries (Sharma et al., 2001; Brigida et al.,2014 ). It is grouped with other non-conventional yeasts which include species such as Pichia pastoris, P. guilliermondii and Kluyveromyces lactis (Spencer et al., 2002). Y. lipolytica is a model microorganism used to study lipid metabolism in the cells of oleaginous organisms (Beopoulos $\boldsymbol{e t}$ al. 2009a), the genus is also a model microorganism for protein secretion, peroxisome biogenesis, the respiratory chain, dimorphism, and hydrophobic substrate utilization (Fickers et al., 2005a). Industrial interest in $Y$. lipolytica has increased in the last half a century from the 1960s when the yeast were used as a source of SCP (single-cell protein). Y. lipolytica is known to have high secretory activity, and among the most desirable metabolites are citric acid, $\gamma$-lactones and enzymes (proteases, RNase, phosphatase, esterase and lipases) (Spencer $\boldsymbol{e t}$ al., 2002; Barth and Gaillardin, 1997).

The lipolytic activity of $Y$. lipolytica was first described by Peters and Nelson (1948a,b), but the genes encoding for lipase proteins (EC 3.1.1.3, triacylglycerol hydrolase) were discovered recently. There are two fractions of $Y$. lipolytica lipases, extracellular (secreted out of the cell) and intracellular (enzymes located in the cytosol and structures associated with the cell wall). The lipases and esterases are encoded by $L I P$ family genes. The $L I P 2$ gene, which encodes for the proenzyme of Lip2p lipase, is the primary source of extracellular lipolytic activity for $Y$. lipolytica (Fickers et al., 2005a; Pereira-Meirelles et al., 2000; Fickers et al., 2011).

Most authors consider olive oil as an excellent carbon source for stimulating the synthesis of lipases in oleaginous yeast, including $Y$. lipolytica. The stimulatory action of olive oil on microbial lipase synthesis is attributed to the high content of oleic acid (from 55 to $83 \%$ ) in the glycerol esters of the vegetable oil, and oleic acid is considered to be an inducer of the LIP2 promotor (Barth and Gaillardin, 1997; Wang et al., 2008; Darvishi et al., 2009). It should be noted, however, that extracellular lipases expressed by different yeast strains are not equally activated by the presence of olive oil and other vegetable oils are sometimes used in the production of microbial lipases (Domínguez et al., 2003).

The objective of our study was to investigate the effect of various vegetable oils on the synthesis of $Y$. lipolytica extracellular lipases in shaken cultures, along with attempt to identify factor(s) influencing enzyme induction in the presence of lipid carbon sources. Ten different vegetable oils were used as carbon sources.
They were chosen according to several criteria. Olive oil was tested as it was the most often used hydrophobic carbon source in microbiological lipase production, as well as conventional oils available in Central and Eastern Europe. Olive oil is not a typical vegetable oil for Central and East European climate zones and is characterized by a relatively high price compared with popular sunflower or rapeseed oils. As the costs of microbial culture medium are 25 to $30 \%$ of the total expenditures for enzyme production, this issue is important for the commercial cultivation of yeast for biocatalytic purposes (Burkert et al., 2004). Additionally, some vegetable oils such as sesame oil and canola oil were used in the study to differentiate the range of substrates used in culture medium. The activity of lipases synthesized by $Y$. lipolytica, in addition to analysis of vegetable oil fatty acid composition, allowed to discuss the role of oleic acid in synthesis of extracellular lipolytic proteins.

\section{MATERIAL AND METHODS}

\section{Chemicals and culture media}

p-nitrophenyl laurate was synthesized in the laboratory (Vogel et al., 1996) Swine pancreatic lipase (100-400 U/mg) and TRIS-HCl buffer $(1 \mathrm{M})$ were purchased from Sigma-Aldrich (Poznań, Poland), bile salts from Fluka (Germany) and other chemicals were purchased from POCH (Gliwice, Poland). YPG medium ( $2 \%$ glucose, $1 \%$ yeast extract, $2 \%$ peptone, $\mathrm{pH} 5.0$ ) and modified YPG medium ( $2 \%$ vegetable oil, $1 \%$ yeast extract, $2 \%$ peptone, $\mathrm{pH} 5.0$ ) were used for the cultivation of yeast, and prepared with distilled water. Glucose, peptone and yeast extract were purchased from BTL (Łódź, Poland). Commercially-available vegetable oils (olive, peanut, rapeseed, grape seed, sunflower, canola with red palm, sesame, flaxseed, corn and rice oils) were used as the sole carbon sources in the medium.

\section{Microorganism and culture conditions}

Y. lipolytica KKP 379 was purchased from the Collection of Industrial Microorganisms at the prof. Wacław Dąbrowski Institute of Agricultural and Food Biotechnology in Warsaw. Y. lipolytica was stored in liquid nitrogen. The inoculum was generated in $100 \mathrm{ml} \mathrm{YPG}$ medium and incubated for $24 \mathrm{~h}$ at $28{ }^{\circ} \mathrm{C}$ in a IKA KS 4000 ic control shaker at $150 \mathrm{rpm}$. Shaken cultures were carried out in $100 \mathrm{ml}$ of liquid medium with vegetable oil as the sole carbon source, where 
$0.1 \% \mathrm{v} / \mathrm{v}$ inoculum was added and incubated for $65 \mathrm{~h}$ at $28^{\circ} \mathrm{C}$ with a rotation of $150 \mathrm{rpm}$. There was chosen the optimal time of incubation for extracellular lipase activity measurement (Fabiszewska, 2013). Yeast biomass was centrifuged in a MPW - 351R centrifuge at $6784 \mathrm{rcf}$ for 10 minutes at $10^{\circ} \mathrm{C}$ and dry cell mass measured by the thermogravimetric method at $105^{\circ} \mathrm{C}$. Yeast biomass yield was determined on the basis of raw biomass weight and dry cell mass.

\section{Determination of lipase activity}

Measures of enzymatic activity were carried out using the spectrophotometric method previously described by Krzyczkowska et al. (2009) and modified according to Kapturowska et al. (2012). The method was based on the hydrolysis of $p$-nitrophenyl laurate, where one unit of enzyme activity was defined as the enzyme quantity that liberated $1 \mu \mathrm{mol}$ of $p$-nitrophenol per minute under the assay conditions at $37^{\circ} \mathrm{C}$.

\section{Fatty acids composition in vegetable oils}

The analysis of fatty acids composition of the triacylglycerols in vegetable oils was carried out after derivatization to methyl esters by the AOCS Ce 1-62 method and evaluation by a gas chromatography system with a FID detector (Agilent Technologies 7890A GC). Separation of fatty-acid methyl esters was accomplished using a Supelcowax 10 capillary column $(30 \mathrm{~m}, 0.32 \mathrm{~mm}, 0.25$ $\mu \mathrm{m})$ with helium as the carrier gas. Autosampler injection was $1 \times 1 \mathrm{ml}$ with a flow distribution of 50:1 and the gradient program was as follows: from $200{ }^{\circ} \mathrm{C}$ to $260{ }^{\circ} \mathrm{C}$ at a rate of $4{ }^{\circ} \mathrm{C} / \mathrm{min}$, then $260{ }^{\circ} \mathrm{C}$ for $10 \mathrm{~min}$. Injector temperature was $250{ }^{\circ} \mathrm{C}$ and detector temperature was $260{ }^{\circ} \mathrm{C}$. Identification of fatty acids was based on peak retention times by comparing with the retention time of standard samples.

\section{Structure of triacylglycerols in vegetable oils}

In order to determine the composition of fatty acids in the triacylglycerols of vegetable oil, a selective enzymatic hydrolysis was performed according to the method developed by the Department of Chemistry at Warsaw University of Life Sciences (Bryś, 2005). For this purpose, $0.4 \mathrm{~g}$ of vegetable oil was added to $8 \mathrm{ml}$ of $1 \mathrm{M}$ Tris- $\mathrm{HCl}, 0.5 \mathrm{ml} 2.2 \%$ calcium chloride solution, $0.2 \mathrm{ml} 1 \%$ aqueous solution of bile salts and $200 \mathrm{mg}$ of pancreatic lipase (regioselective lipase specific to the sn- 1,3 bonds in the molecules of triacylglycerols) was added to start the hydrolysis $\left(40{ }^{\circ} \mathrm{C}, 20 \mathrm{~min}\right)$. The reaction was stopped by addition of 15 $\mathrm{ml}$ of ethanol and $5 \mathrm{ml} 6 \mathrm{M}$ hydrochloric acid, hydrolysis products were extracted with diethyl ether and dried with magnesium sulfate. An extract was applied to silica gel TLC plates, the plates were washed with a solution of hexane, diethyl ether and acetic acid (50:50:1) and developed with iodine. The 2monoacylglycerols were extracted with $20 \mathrm{ml}$ of diethyl ether, and after gel filtration, the solvent was removed using a rotary evaporator (Büchi R-200/B490) and the 2-monoacylglycerols dissolved in $2 \mathrm{ml}$ hexane.

After derivatization to methyl esters according to DIN EN ISO 5509:2000 method, the fatty acid composition was determined using an YL6100 gas chromatograph coupled with a FID detector. Separation of compounds was accomplished on BPX70 column $(60 \mathrm{~m}, 0.25 \mathrm{~mm}$ and $0.25 \mu \mathrm{m})$ using nitrogen as the carrier gas and a phase flow of $1.2 \mathrm{ml} / \mathrm{min}$. The gradient program was as follows: $70^{\circ} \mathrm{C}$ for $0.5 \mathrm{~min}$; from 70 to $160{ }^{\circ} \mathrm{C}$ at a rate of $15^{\circ} \mathrm{C} / \mathrm{min}$, from 160 to $200{ }^{\circ} \mathrm{C}$ at a rate of $1.1^{\circ} \mathrm{C} / \mathrm{min}, 200^{\circ} \mathrm{C}$ for $12 \mathrm{~min}$, from 200 to $225^{\circ} \mathrm{C}$ at a rate of $30{ }^{\circ} \mathrm{C} / \mathrm{min}$ and $225{ }^{\circ} \mathrm{C}$ for $1 \mathrm{~min}$. Injector temperature was $225{ }^{\circ} \mathrm{C}$ and detector temperature $250^{\circ} \mathrm{C}$. Identification of fatty acids was based on peak retention time by comparing with the retention time of standard samples.

\section{Statistical analysis}

Statistical analyses were performed of repeated measurements with one-way ANOVA followed by Tukey's multiple comparison test and analysis of correlation using STATISTICA 10.0 (Statsoft, Poland). P-values of $\mathrm{p} \leq 0.05$ were considered to be statistically significant. The Shapiro-Wilk test was used to check if the populations were normally distributed, while Levene's test and the BrownForsythe test were used to assess the equality of variances for a variable calculated for groups. All experiments were repeated 5 times.

\section{RESULTS}

Y. lipolytica KKP 379 were incubated (shaken cultures) in media containing vegetable oil as the sole carbon source (peanut, rice, sesame, flaxseed, grape seed, sunflower, rapeseed, canola with red palm, olive and corn oil) and assayed after $65 \mathrm{~h}$ for biomass yield and extracellular lipase activity (Fig. 1 and 2). The highest average biomass yield $\left(16.6 \mathrm{~g} \mathrm{~d} . \mathrm{m} . / \mathrm{dm}^{3}\right)(\mathrm{d} . \mathrm{m} .-$ dry mass) was obtained in medium where peanut oil was used as the sole carbon source (Fig. 1). Significantly lower biomass yields were achieved in flaxseed and corn oil media, at 10.5 and $13.1 \mathrm{~g} \mathrm{~d} . \mathrm{m} . / \mathrm{dm}^{3}$, respectively. For the remaining seven oils, biomass yield did not differ significantly from that in peanut oil medium.
Greater variability was seen for extracellular lipase activity (Fig. 2). The highest average lipolytic activity was found in the supernatant from the corn oil medium $\left(0.362 \mathrm{U} / \mathrm{cm}^{3}\right)$ and lower activity was seen in canola and red palm oil medium $\left(0.280 \mathrm{U} / \mathrm{cm}^{3}\right)$, though this difference was not statistically significant from corn oil. The lowest activity was seen for peanut and rice oil media (0.068 and 0.089 $\mathrm{U} / \mathrm{cm}^{3}$ respectively). The activity was 2 -fold higher when flaxseed, sesame and grape seed oil media $\left(0.137,0.151\right.$ and $0.151 \mathrm{U} / \mathrm{cm}^{3}$, respectively) were used, though with respect to the latter two oils, the differences were not statistically significant. These five oils were classified into the same homogeneous group.

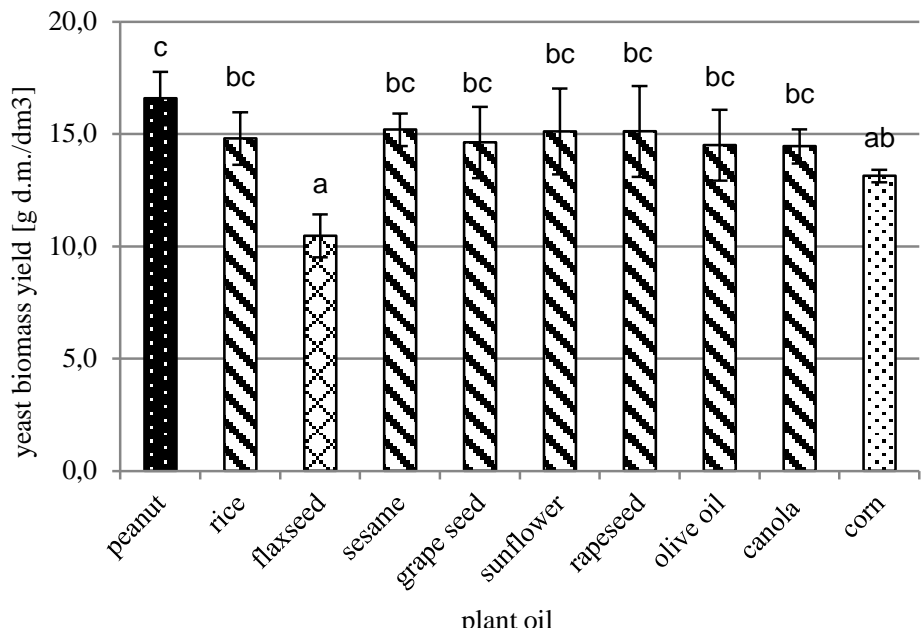

Figure 1 Influence of vegetable oil on Y. lipolytica KKP 379 biomass yield after $65 \mathrm{~h}$ of shaking culture. Homogeneous groups designated on the basis of Tukey's test were identified by letters and different posts. Means were separated into statistically different groups ( $a, a b, b c$ and $c)$.

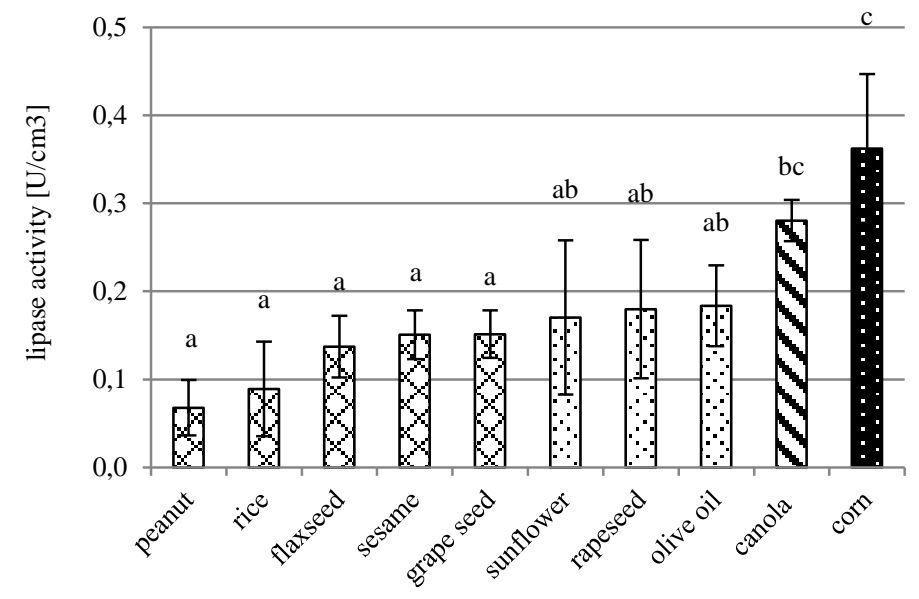

plant oil

Figure 2 Influence of the vegetable oil on extracellular Y. lipolytica KKP 379 lipase activity after $65 \mathrm{~h}$ of shaking culture. Homogeneous groups designated on the basis of Tukey's test were identified by letters and different posts. Means were separated into statistically different groups (a, ab, bc and c).

Intention of the authors was to correlate lipolytic activity with fatty acid composition for each oil used in the study. All oils had a high content of unsaturated fatty acids in the triacylglycerol molecules (Codex Alimentarius), where the differences in physicochemical and sensory properties of these oils are due to fatty acid composition. Fatty acid composition was determined for each oil (Table 1), which coincided with the characteristics in the Codex Alimentarius and papers by Przybylski et al. (2005a,b). The highest oleic acid content (C 18:1) was found in olive oil (over $70 \%$ of the fatty acid content) and the highest palmitic acid content was measured in canola $(12.53 \%)$ and rice oils $(15.23 \%)$ (Table 1). Grape seed, sunflower (extracted from sunflower seeds) and corn oils (derived from maize embryos) were characterized by a high percentage of linoleic acid (C 18:2), which accounted for greater than $50 \%$ of all fatty acids in the oils. Flaxseed oil was characterized by a high content $(52.65 \%)$ of polyunsaturated linolenic acid (C 18:3), also found in rapeseed $(8.08 \%)$ and canola oils $(6.01 \%)$. Peanut oil was characterized by a relatively high content of behenic acid (C 22:0, $2.62 \%)$ and lignoceric acid (C 24:0, $1.39 \%)$, while rice oil had a high palmitoleic acid content (C 16:1, $4.06 \%)$. 
Table 1 Fatty acid composition of vegetable oils [\% total fatty acid content in oil]

\begin{tabular}{|c|c|c|c|c|c|c|c|c|c|c|c|}
\hline $\begin{array}{l}\text { Fatty acids } \\
\text { symbol }\end{array}$ & $\begin{array}{l}\text { Fatty acids } \\
\text { name }\end{array}$ & $\begin{array}{l}\text { Peanut } \\
\text { oil }\end{array}$ & Rice oil & $\begin{array}{l}\text { Flaxseed } \\
\text { oil }\end{array}$ & $\begin{array}{l}\text { Sesame } \\
\text { oil }\end{array}$ & $\begin{array}{c}\text { Grape } \\
\text { seed } \\
\text { oil }\end{array}$ & $\begin{array}{l}\text { Sunflowe } \\
\text { r oil }\end{array}$ & $\begin{array}{l}\text { Rapeseed } \\
\text { oil }\end{array}$ & Olive oil & $\begin{array}{c}\text { Canola and } \\
\text { red palm oil }\end{array}$ & Corn oil \\
\hline C14:0 & Myristic acid & 0.03 & 0.26 & 0 & 0.02 & 0.07 & 0.07 & 0.05 & 0 & 0.29 & 0.03 \\
\hline C16:0 & Palmitic acid & 9.47 & 15.23 & 5.87 & 9.32 & 8.06 & 6.62 & 4.05 & 10.27 & 12.53 & 11.06 \\
\hline C16:1 & $\begin{array}{c}\text { Palmitooleic } \\
\text { acid }\end{array}$ & 0.13 & 4.06 & 0.07 & 0.15 & 0.15 & 0.13 & 0.24 & 0.81 & 0.25 & 0.13 \\
\hline C17:0 & Margaric acid & 0.07 & 0.04 & 0.06 & 0.04 & 0.05 & 0.04 & 0.05 & 0.07 & 0.06 & 0.06 \\
\hline C17:1 & $\begin{array}{l}\text { Margarooleic } \\
\text { acid }\end{array}$ & 0.05 & 0.02 & 0 & 0 & 0.04 & 0.03 & 0.09 & 0.13 & 0.06 & 0.03 \\
\hline C18:0 & Stearic acid & 3.53 & 2.06 & 4.35 & 5.77 & 3.8 & 3.27 & 1.93 & 3.15 & 2.37 & 1.78 \\
\hline C18:1 & Oleic acid & 59.26 & 44.93 & 20.38 & 40.05 & 25.39 & 30.4 & 64.47 & 77.86 & 57.35 & 28.38 \\
\hline C18:2 & Linoleic acid & 19.96 & 30.26 & 15.85 & 43.19 & 60.45 & 58.25 & 18.47 & 6.17 & 18.66 & 56.31 \\
\hline C18:3 & $\begin{array}{l}\text { Linolenic } \\
\text { acid }\end{array}$ & 0.5 & 0.93 & 52.65 & 0 & 0.85 & 0.05 & 8.08 & 0.63 & 6.01 & 0.8 \\
\hline C20:0 & $\begin{array}{l}\text { Arachidic } \\
\text { acid }\end{array}$ & 1.47 & 0.87 & 0.16 & 0.62 & 0.27 & 0.24 & 0.58 & 0.41 & 0.53 & 0.41 \\
\hline C20:1 & - & 1.15 & 0.53 & 0.10 & 0.19 & 0.19 & 0.16 & 1.26 & 0.29 & 0.98 & 0.28 \\
\hline C22:0 & Behenic acid & 2.62 & 0.26 & 0.16 & 0.13 & 0.41 & 0.78 & 0.3 & 0.11 & 0.25 & 0.12 \\
\hline C22:1 & Erucic acid & 0.21 & 0.06 & 0 & 0 & 0.05 & 0.04 & 0.07 & 0 & 0 & 0 \\
\hline C24:0 & $\begin{array}{l}\text { Lignoceric } \\
\text { acid }\end{array}$ & 1.39 & 0.42 & 0.12 & 0.08 & 0.16 & 0.24 & 0.16 & 0.05 & 0.13 & 0.17 \\
\hline C24:1 & Nervonic acid & 0 & 0 & 0 & 0 & 0 & 0 & 0.12 & 0 & 0.12 & 0 \\
\hline
\end{tabular}

Table 2 Correlation ratios for the relationship between Y. lipolytica KKP 379 biomass yield, extracellular lipolytic activity and individual fatty acid content of triacylglycerols in vegetable oils. Coefficients with an asterisks were statistically significant.

\begin{tabular}{|c|c|c|}
\hline Correlated feature, a content of fatty acid in oil & Extracellular lipolytic activity & Biomass yield \\
\hline \multicolumn{3}{|c|}{ According to all positions ( $s n-1, s n-2$ and $s n-3)$ for all tested oils } \\
\hline C14:0 & 0.079940 & 0.173209 \\
\hline C16:0 & 0.115897 & 0.173501 \\
\hline C16:1 & -0.341705 & 0.110367 \\
\hline C17:0 & 0.178193 & -0.143933 \\
\hline $\mathrm{C} 17: 1$ & 0.136691 & 0.324232 \\
\hline C18:0 & -0.428441 & -0.065694 \\
\hline C18:1 & -0.091586 & 0.528368 \\
\hline C18:2 & 0.243609 & 0.090760 \\
\hline $\mathrm{C} 18: 3$ & -0.116265 & $-0.842646^{*}$ \\
\hline C20:0 & -0.450066 & $0.648235^{*}$ \\
\hline $\mathrm{C} 20: 1$ & -0.085839 & 0.502861 \\
\hline $\mathrm{C} 22: 0$ & -0.478569 & 0.539497 \\
\hline $\mathrm{C} 22: 1$ & -0.583727 & 0.601967 \\
\hline $\mathrm{C} 24: 0$ & -0.502063 & 0.500337 \\
\hline $\mathrm{C} 24: 1$ & 0.320873 & 0.125692 \\
\hline Sum of saturated fatty acids & -0.236866 & 0.371906 \\
\hline Sum of unsaturated fatty acids & 0.202387 & -0.340217 \\
\hline \multicolumn{3}{|c|}{$\begin{array}{l}\text { According to } s n-1 \text { and } s n-3 \text { positions for five selected oils } \\
\text { (corn oil, canola and red palm oil, olive oil, rice oil and peanut oil) }\end{array}$} \\
\hline $\mathrm{C} 16: 0$ & -0.100567 & -0.241602 \\
\hline $\mathrm{C} 18: 0$ & -0.751072 & 0.864908 \\
\hline $\mathrm{C} 18: 1$ & -0.492777 & 0.596541 \\
\hline $\mathrm{C} 18: 2$ & 0.622278 & -0.692906 \\
\hline Sum of unsaturated fatty acids & 0.758170 & -0.520597 \\
\hline
\end{tabular}

The concentrations of individual fatty acids in vegetable oils were correlated with $Y$. lipolytica KKP 379 biomass yield and extracellular lipolytic activity. Literature reports oleic acid (C18: 1) and linoleic acid (C18: 2) as stimulators of lipase microbial activity (Fickers et al., 2005a; Wang et al., 2008; Fickers et al., 2005b), therefore, a high oleic acid concentration was expected to affect synthesis and activity of yeast lipases. Contrary to expectations, there was no significant correlation between these two dependent variables and the percentage of particular fatty acids in triacylglycerols or the percentage of saturated and unsaturated fatty acids in triacylglycerols (Table 2). The content of oleic acid did not explain the highest extracellular lipase activity in the corn oil medium (28.38\%), while in the olive oil medium, lipolytic activity was significantly reduced, even though olive oil contained the highest amount of C18:1 acid among all the oils $(77.86 \%)$. Extracellular lipolytic activity was lowest in the presence of rice and peanut oils, which were characterized by a two-fold higher content of oleic acid (44.93 and 59.26\%, respectively) in comparison to corn oil. No correlation was seen between linoleic acid content and $Y$. lipolytica lipase 
activity (Table 2). The average amount of linoleic acid in the corn oil was $56.31 \%$ of the total fatty acid content, while grape seed oil $(60.45 \%)$ and sunflower oil $(58.25 \%)$ were characterized by a higher concentration of this compound, and olive oil at $6.17 \%$ (C18:2 acid).

$Y$. lipolytica synthesizes $s n$-1,3-regioselective extracellular lipase Lip2 (Fickers et al., 2011; Hadebal, 1991), and the main products of lipase-catalysed triglyceride hydrolysis were 2-monoacylglycerols and free fatty acids. The hypothesis was that high lipolytic activity would be associated with the content and type of fatty acids present at the $s n-1$ and $s n-3$ positions in the triacylglycerols. The existence of such a relationship was evaluated by examining the structure of the five selected vegetable oils (Table 3) which had the greatest impact on lipase activity: peanut and rice oil (characterized as weak inducers of lipolytic activity) as well as corn, olive, canola with red palm oil. A detailed analysis of the triacylglycerol structure yielded fatty acid contents at the external positions of glycerol esters $(s n-1,3)$. Table 3 shows which fatty acids were dominant in the selected vegetable oils and their content (greater than $1.5 \%$ ). However according to the data in Table 3 no correlations were found between lipolytic activity and vegetable oil parameters (Table 3). Regardless, a detailed description of all oils is given (Table 4), which confirmed that while the oils differed significantly in chemical composition, there was no direct relationship between extracellular lipase activity, total content of unsaturated fatty acids in the triacylglycerol molecule or their concentration at the $s n-1,3$ or $s n-2$ positions (Table 3 and 4). Moreover, the percentage of unsaturated fatty acids at the $s n-1,3$ positions of triacylglycerols in peanut and rice oils (50.3 and $45.5 \%$, respectively) were lower compared to olive, canola and the corn oils $(54.8,52.5$ and $55.9 \%$, respectively), but not sufficiently significant to play an important role in the induction of lipase expression in yeast cells.
Table 3 The structure of triacylglycerols in individual vegetable oils.

\begin{tabular}{|c|c|c|c|}
\hline \multirow[t]{2}{*}{ Fatty acid } & \multirow[t]{2}{*}{$\begin{array}{c}\text { Summary content } \\
\text { of particular fatty } \\
\text { acid in oil [\%] }\end{array}$} & $\begin{array}{c}\text { Content of a } \\
\text { particular fatty } \\
\text { acid in } s n-1,3 \text { or } \\
s n-2 \text { position [\%] } \\
\end{array}$ & \multirow[t]{2}{*}{$\begin{array}{l}\text { Portion of a particula } \\
\text { fatty acid in } s n-1,3 \\
\text { positions } \\
{[\%]_{* *}^{*}}\end{array}$} \\
\hline & & $s n-2^{*}$ & \\
\hline
\end{tabular}

\section{Peanut oil}

(lipase activity $0.068 \mathrm{U} / \mathrm{cm}^{3}$ )

\begin{tabular}{|l|c|c|c|c|}
\hline C $16: 0$ & 9.47 & 10.4 & 9.0 & 6.0 \\
\hline C $18: 0$ & 3.53 & 3.0 & 3.8 & 2.5 \\
\hline C $18: 1$ & 59.26 & 42.7 & 67.5 & 45.0 \\
\hline C $18: 2$ & 19.96 & 43.9 & 8.0 & 5.3 \\
\hline
\end{tabular}

C 18:2

19.96

Rice oil

(lipase activity $0.089 \mathrm{U} / \mathrm{cm}^{3}$ )

\begin{tabular}{|l|c|c|c|c|}
\hline C 16:0 & 15.23 & 9.0 & 18.3 & 12.2 \\
\hline C $18: 0$ & 2.06 & 1.8 & 2.2 & 1.5 \\
\hline C $18: 1$ & 44.93 & 53.5 & 40.6 & 27.1 \\
\hline C $18: 2$ & 30.26 & 35.6 & 27.6 & 18.4 \\
\hline
\end{tabular}

Olive oil

(lipase activity $0.184 \mathrm{U} / \mathrm{cm}^{3}$ )

\begin{tabular}{|l|c|c|c|c|}
\hline C $16: 0$ & 10.27 & 9.4 & 10.7 & 7.1 \\
\hline C $18: 0$ & 3.15 & 3.0 & 3.2 & 2.2 \\
\hline C $18: 1$ & 77.86 & 71.0 & 81.3 & 54.2 \\
\hline C $18: 2$ & 6.17 & 16.6 & 1.0 & 0.6 \\
\hline
\end{tabular}

Canola and red palm oil

(lipase activity $0.280 \mathrm{U} / \mathrm{cm}^{3}$ )

\begin{tabular}{|l|c|c|c|c|}
\hline C $16: 0$ & 12.53 & 9.0 & 14.3 & 9.5 \\
\hline C $18: 0$ & 2.37 & 2.2 & 2.5 & 1.6 \\
\hline C $18: 1$ & 57.35 & 57.0 & 57.5 & 38.4 \\
\hline C $18: 2$ & 18.66 & 26.6 & 14.7 & 9.8 \\
\hline C $18: 3$ & 6.01 & 5.2 & 6.4 & 4.3 \\
\hline $\begin{array}{l}\text { Corn oil } \\
\text { (lipase activity } 0.362 \mathrm{U} / \mathrm{cm}^{3} \text { ) }\end{array}$ \\
\hline C $16: 0$ & 11.06 & 10.3 & 11.4 & 7.6 \\
\hline C $18: 0$ & 1.78 & 3.3 & 1.0 & 0.7 \\
\hline C $18: 1$ & 28.38 & 42.7 & 21.2 & 14.2 \\
\hline C $18: 2$ & 56.31 & 43.7 & 62.6 & 41.7 \\
\hline
\end{tabular}

Legend: * Content of a particular fatty acid based upon the content of all fatty acids in the sn-2 position of the triacylglycerol; ** Content of a particular fatty acid based upon the content of all fatty acids in the sn-1,3 positions of the triacylglycerol; *** Portion of a particular fatty acid at the sn-1,3 positions based upon the content of individual fatty acids in oil minimized by the content of fatty acid in sn- 2 position

Table 4 Characteristics of vegetable oils used in media for the cultivation of $Y$. lipolytica. Oils are ranked according to increasing lipolytic activity, and the letters denote statistical differences in lipase activity seen in Figure 2

\begin{tabular}{|l|c|c|c|c|}
\hline Vegetable oil & $\begin{array}{c}\text { Content of saturated } \\
\text { fatty acids in oil [\%] }\end{array}$ & $\begin{array}{c}\text { Content of unsaturated } \\
\text { fatty acids in oil [\%] }\end{array}$ & $\begin{array}{c}\text { Unsaturated and } \\
\text { saturated } \\
\text { fatty acids ratio }\end{array}$ & $\begin{array}{c}\text { Content of unsaturated } \\
\text { fatty acids in oil in } \\
\text { sn-1,3 position [\%] }\end{array}$ \\
\hline Peanut oil $^{\text {a }}$ & 18.7 & 81.3 & $4.3: 1$ & 50.3 \\
\hline Rice oil $^{\text {a }}$ & 19.2 & 80.8 & $4.2: 1$ & 45.5 \\
\hline Olive oil $^{\text {ab }}$ & 14.1 & 85.9 & $6.1: 1$ & 54.8 \\
\hline Canola and red palm oil bc $^{\text {be }}$ & 16.5 & 83.5 & $5.1: 1$ & 52.5 \\
\hline Corn oil $^{\mathbf{c}}$ & 14.1 & 85.9 & $6.1: 1$ & 55.9 \\
\hline
\end{tabular}

\section{DISCUSSION}

Y. lipolytica has been widely investigated for lipase activity in media containing various carbon sources, as yeast can efficiently degrade and oxidise many hydrophobic substrates such as fats, oils, alkanes and fatty acids (Fickers $\boldsymbol{e t}$ al., 2005a). It is well known that the presence of glucose inhibits extracellular lipase activity, and supplementation with a stimulator is necessary to induce synthesis of the enzyme (Fickers et al., 2003, 2005a,b). It should be mentioned that glucose demonstrated a repressive mechanism also on Y. lipolytica KKP 379 lipase production (Fabiszewska et al., 2014), so the addition of hydrophobic carbon source to the YP medium was essential. Lipid carbon sources are convenient substrates for lipase production, and one of the best lipase inducers, olive oil, has a high oleic acid content (Fickers et al., 2005a); some other plant oils were investigated as well (Darvishi et al., 2009; Domínguez et al., 2003). A thorough review of the current state of art in the field of inducers of lipase synthesis and an attempt to suggest possible interpretations in view of our results will be presented in course of discussion. As the correlation between lipase activity and fatty acid content in vegetable oil used as carbon source failed, some new hypothesis has been formulated why $Y$. lipolytica yeast produce lipases with various activity in medium with different vegetable oils.

\section{Fatty acids in microbial lipases synthesis}

As it was described above olive oil is considered an extracellular lipase activator due to the $55-83 \%$ content of oleic acid, which is an inducer of the LIP2 gene promotor (Fickers et al., 2005a). The existence of two pathways regulating LIP2 gene expression was suggested (Fickers et al., 2011). One involves $\beta$-oxidation and is related to $P O X 2$ gene regulation, which is sensitive to the presence of fatty acids (Gurvitz et al., 2006), while the second is regulated SOA-related genes and associated with triacylglycerol metabolism (Desfougères et al. 2009).

Fickers et al. (2004) observed the highest LIP2 gene activity in a modified strain of $Y$. lipolytica $(\operatorname{LgX64.81)}$ in the presence of $0.5 \%$ oleic acid, but failed to confirm a direct correlation between the level of LIP2 gene expression and lipase synthesis. However, it was suggested that lipase synthesis could be regulated at the level of secretion and therefore, the higher the extracellular lipase activity, the more enzymatic proteins were transported from the interior of the cell into the environment (Fickers et al., 2004). Oleic acid present in olive oil was considered the best inducer of lipolytic activity in $R$. chinensis CCTCC M201021 (Wang et al., 2008), and Hsu et al. (2008) reported that olive oil and oleic acid induced translation of genes encoding lipolytic enzymes in C. rugosa. 
These observations are contradicted in the present study and also by other authors. For example Dalmau et al. (2000), observed maximum C. rugosa ATCC 14830 extracellular lipase activity in a medium containing palmitic acid as the sole carbon source. The highest activity of cell-bound lipase was achieved with a triolein substrate, while oleic acid stimulated lipase synthesis, but to a much lesser extent than other lipid carbon sources (Dalmau et al., 2000). C. rugosa ATCC 14830 was also used by Wei $\boldsymbol{e t}$ al. (2004) to study the stimulatory effect of selected fatty acids on lipase synthesis, and the highest lipase activity was seen in oleic acid-containing medium. Of note, no lipase synthesis was observed when myristic acid or dodecanoic acid were used. Enzyme activity was also affected by fatty acid carbon chain length (greater number of carbon atoms in the chain results in higher specific activity of yeast enzymes) and the presence of unsaturated bonds in the molecule (higher activity observed in medium containing oleic acid than with stearic acid) (Wei et al., 2004).

Interestingly, Corzo and Revah (1999) reported oleic acid $\left(12 \mathrm{~g} / \mathrm{dm}^{3}\right)$ as a lipase inhibitor for $Y$. lipolytica 681 , while the presence of oleic acid exceeding $2 \mathrm{~g} / \mathrm{dm}^{3}$ in the culture medium resulted in a significant reduction in the level of lipase expression for $C$. rugosa (Gordillo et al., 1995). Oleic acid was the final product of triacylglycerol hydrolysis and a reduction in lipolytic activity due to product inhibition may have occurred.

Some authors postulate that extensive absorption of oleic acid inside cells of $C$. rugosa coincides with intensive secretion of extracellular lipases. In turn, a smal amount of lipase is essential for the hydrolysis of triacylglycerols to glycerol and free fatty acids (Montesinos et al., 1996). This hypothesis complements the conclusions of Pereira-Meirelles et al. (2000) reporting high extracellular $Y$ lipolytica lipase activity was associated with the lipid carbon source depletion in the medium.

Although, the authors of the present study did not use oleic acid as an individual carbon source in medium, they have proved that high content of this fatty acid in vegetable oil did not correspond with high extracellular lipase activity. It is possible that for $Y$. lipolytica KKP 379 strain oleic acid (as the final product of triacylglycerol hydrolysis of olive oil) could even act as an inhibitor in lipase synthesis as it suggested Corzo and Revah (1999).

\section{Vegetable oils in microbial production of lipases}

Vegetable oils have been used in the microbial production of lipases, and hydrophobic carbon sources are suitable substrates activating the synthesis of lipolytic enzymes in yeast and filamentous fungi (Wang $\boldsymbol{e t}$ al., 2008; Darvishi $\boldsymbol{e}$ al., 2009). It is noteworthy that diverse strains of $Y$. lipolytica have different preferences for the lipid substrate used in the culture medium (Guerzoni $\boldsymbol{e t}$ al., 2001) depending on different metabolic activity. Thus, for the purposes of the study a wild-type strain $Y$. lipolytica KKP 379 was used to determine the different extracellular lipase activity in medium with vegetable oils. It should be also mentioned that so far there is no single universal method for determining the activity of triacylglycerol hydrolases, so it was impossible to compare the results taking the values of lipolytic activity into account, but we were able to compare the final effect observed in each study.

According to Domínguez et al. (2003), biomass yield of Y. lipolytica CECT 1240 (ATCC 18942) culture in medium supplemented with glucose, oleic acid, olive oil or sunflower oil was independent of the presence of lipid carbon sources, but the hydrophobic carbon source determined the final activity of extracellular lipases, indicating some vegetable oils can stimulate lipase activity to a greater extent than olive oil. For $Y$. lipolytica CECT 1240, higher lipase activity was achieved in culture with sunflower oil rather than olive oil (Domínguez et al., 2003), while olive oil and corn oil were considered the best inducers of lipase synthesis in Y. lipolytica 681. The use of vegetable oils as the sole carbon source in the medium resulted in satisfactory yeast biomass yields compared to medium containing glucose (Beopoulos et al., 2009a). Corzo and Revah (1999) investigated the substrate specificity of $Y$. lipolytica 681 lipases and the enzyme had the same activity when hydrolysing olive oil, tributyrin and tricaprilin substrates. Significantly lower lipase activity was achieved when triolein was used, and the lowest activity with corn oil (Corzo and Revah, 1999). Kebabci and Cihangir (2012) evaluated the effect of vegetable oils (olive, extra-virgin olive, canola, corn, sunflower and soybean oils) as the sole carbon source on lipase production by three different strains of $Y$. lipolytica (NBRC 1658, IFO 1195 and a local wild-type strain). Maximum lipolytic activity was seen for $Y$. lipolytica NBRC 1658 in canola oil medium and Y. lipolytica IFO 1195 in soybean oil medium, while the carbon source had no effect on the synthesis of lipases by the local wild-type strain. No significant differences in growth were seen in media containing vegetable oils, though various yeast strains did have a preference with respect to the vegetable oil, which can stimulate lipolytic activity (Kebabci and Cihangir, 2012).

Our results on the lipase-activating role of olive oil are similar to those obtained by some other authors. They do not support the thesis that olive oil is the best lipase inducer. Moreover, the few results presented by other authors claimed that corn oil could be a better lipase activator in culture medium. Unfortunately, none of authors had explained any reason of the observation. In our study we have managed to show that the high lipase activity may not be correlated with the fatty acid content in vegetable oil used as carbon source in culture medium.

\section{Lipid metabolism in Y. lipolytica cells}

Papanikolaou et al. (2001) demonstrated that during the growth of yeast cells in media containing a lipid carbon source, synthesis, modification of the lipid composition and the accumulation of intracellular lipid fractions occurs. Lipids, which are accumulated in the form of lipid bodies inside the yeast cell, may impede the absorbance of free fatty acids from the environment. When considerable amounts of triglycerides are stored in the cell, lipids inside the cell are utilized by the microorganism, which is energetically favourable compared to the transport of substrate from the external environment.

$Y$. lipolytica cells can accumulate fatty acids in the form of lipid bodies by de novo synthesis from fatty acids precursors such as acetyl-CoA and malonyl-CoA, or by an ex novo mechanism from fatty acids present in the culture medium (Beopoulos et al., 2009a,b). Papanikolaou et al. (2002, 2003) suggested that de novo synthesis may also occur from free fatty acids in the yeast cell. These studies suggest the activation of lipase expression may be related to the accumulation of specific fatty acids inside yeast cells, whereas de novo synthesis of lipid compounds is insufficient. Hence, the yeast cells increase lipase synthesis to obtain these compounds from the environment (Beopoulos et al., 2009a,b; Papanikolaou et al., 2002).

\section{Stereoselectivity of $s n-1,3$ lipases}

A review of literature addressing the substrate specificity of $Y$. lipolytica lipases with respect to the fatty acids in outer positions $(s n-1,3)$ of the triacylglycerol molecules indicated that lipases show little tendency toward stereospecific hydrolysis of ester bonds differentiating between the $s n-1$ or $s n-3$ position According to Aloulou et al. (2007), the Lip2p enzyme synthesized by $Y$ lipolytica showed a slight stereospecificity towards the $s n-3$ position of glycerol trioleate. Further research could also evaluate the stereospecificity of the lipases produced by $Y$. lipolytica KKP 379 and the triacylglycerol structure of vegetable oils, where these two positions are compared (treated as equal in this study). This may serve to explain the effect of vegetable oil type in the culture medium on $Y$. lipolytica lipolytic activity. Furthermore, despite a symmetrical arrangement of the fatty acids at $s n-1$ and $s n-3$ positions, some important differences in the acid content at the outer positions were shown inter alia for corn oil (Brockerhoff and Yurkowski, 1966).

There are two possibilities for desymmetrization of the molecule, the enantiospecific hydrolysis of one enantiomer in a racemic mixture or discrimination between two ester groups in a prochiral molecule containing two identical acyl groups at the $s n-1$ and $s n-3$ positions. The latter effect is well known for different lipases, for example, Candida antarctica B lipase, which catalyses the desymmetrization of 3-alkylglutaric acid diesters (Jung et al., 2013). The highest enantiomeric excess was achieved in the case of allyl esters owing to interactions between the olefin bond and the hydrophobic amino acids residues at the enzyme active site. The olefin drives the favourable conformation change in the first tetrahedral intermediate, called the "olefin effect". The "olefin effect" between the substrate and enzyme is the critical factor increasing the enantioselectivity of $C$. antarctica B lipase-catalysed desymmetrization of prochiral 3-alkylglutaric acid diallylesters (Jung et al., 2013).

In the case of triacylglycerols, this problem was investigated using trioctanoin and triolein as model compounds. Hydrolysis reactions were carried out in the presence of 25 different lipases, where 17 catalysed the reaction at the $s n-1$ position for triolein, and 12 at the $s n-1$ position of trioctanoin. The enantiomeric excess varied from $100 \%$ (for bacterial lipase from Pseudomonas aeruginosa and Pseudomonas sp. for $s n-1$ and Candida antarctica A lipase for $s n-3)$ to $3 \%$, and was lower with triolein than with trioctanoin (Rogalska et al., 2000).

\section{Enzyme-surfactant interactions and uptake of fatty acid into the yeast cell}

The first stage of fatty acid assimilation is contact between the molecule and the yeast cell surface. There are two hypotheses concerning the mechanisms, one of which involves the direct adhesion of the acid molecules to a special cell structures activated by oleic acid or other fatty acids. Several modifications in cell structure were identified, likely related to hydrophobic substrate transport, e.g., protrusions at the cell surface, decreased thickness of the cell wall and periplasmic space as well as membrane invaginations. Many findings support the second hypothesis that surfactants such as liposan, synthesized directly by the yeast $Y$. lipolytica can facilitate uptake of fatty acids due to their emulsifying properties (Fickers et al., 2005a). The differences between lipolytic enzyme activity for yeast cells cultivated in medium with different vegetable oils may be related to the activation of the surfactant synthesis. Reis et al. (2009) reported that lipases are activated by binding to an insoluble emulsified substrate, and the rate of triglyceride lipolysis depends strongly on the specific area of the emulsion drops. Therefore, enzyme-surfactant interactions have an important impact on the regulation of lipase catalysis and the so called "quality of interface" (Reis $\boldsymbol{e t}$ al., 2009). Moreover, a self-regulatory system was discovered for sn-1,3regioselective pancreatic lipase. Released after triacylglycerol hydrolysis, amphiphilic $s n-2$ monoacylglycerols quickly fill the interface between the hydrophilic and hydrophobic phases, displacing free fatty acids, glycerol, 
triacylglycerols compounds and even lipase molecules. Therefore, the decrease in substrate concentration (triglyceride) and the increase in product concentrations cause a reduction in the number of enzyme molecules present at the interface (Reis et al., 2009). Due to the existence of many similarities between the properties of pancreatic lipase and the lipolytic enzymes of $Y$. lipolytica (Najjar et al., 2011), a similar reaction mechanism is expected for both.

Composition of vegetable oils and its correlation with $Y$. lipolytica lipase activity

Vegetable oils are multi-component mixtures, in which triacylglycerols constitute the largest part (over 90\%). Oils also contain free fatty acids, mono- and diacylglycerols, phospholipids, metal ions, peroxides, waxes, sterols, chlorophylls, carotenoids, tocopherols and phenolic compounds (Choe et al. 2006). An important parameter characterizing vegetable oils is the content of free fatty acids, which is measured by the acidic number (number of $0.1 \mathrm{~N} \mathrm{KOH} \mathrm{mg}$ which neutralizes $1 \mathrm{~g}$ of oil). Perhaps, the initial concentration of free fatty acids determined the level of lipase synthesised by Yarrowia, which was supported by the work of Kohlwein and Paltauf (1984), suggesting the existence of at leas two membrane transporter systems in Y. lipolytica (formerly Saccharomycopsis lipolytica) for fatty acids with chain lengths of 12 to 14 and 16 to 18 carbon atoms. The transport of these compounds can be determined by the concentration of fatty acids in the culture medium, and a high content of free fatty acids may have a negative effect on the synthesis of lipases.

Lipolysis of triacylglycerides generates highly interfacial active molecules that can compete with the enzyme at the interface and/or modify the protein activity via molecular interactions (Reis et al., 2009). Amphiphilic molecules (including the fatty acids, mono- or diacylglycerols) can form three-dimensional structure called micelles. In aqueous solutions containing low concentrations of the amphiphilic componds, the molecules are single and gradually adsorbed at the interface, and after saturation of the interface, the concentration of amphiphilic products increases and micelles begin to form. The parameter, which describes the concentration of the amphiphilic compound in solution, above which it exists in an aggregated form, is the critical micelle concentration (CMC). Lipases are enzymes which catalyse a reaction at the interface, and the optimal concentration of enzyme molecules and triacylglycerols at the interface should be maintained. Furthermore, lipase access to substrate molecules is affected by micelle formation and limited availability of the triacylglycerol substrate to the enzyme active site (Guerzoni et $\boldsymbol{a l}$., 2001). Not to mention the fact that products of triglyceride lipolysis change the $\mathrm{pH}$ of the aqueous phase, which can strongly affect the protein-ionic surfactant and protein-substrate interactions (Reis $\boldsymbol{e t}$ al., 2009). $\mathrm{pH}$ also had a strong influence on the active conformation of the lipase catalytic site due to the impact on amino acid protonation of the enzyme molecule.

Sterols, besides triacylglycerols, are lipid compounds stored in yeast cells in the form of lipid bodies, and are a very important cell building blocks involved in the biosynthesis and selective permeability of cell membranes as well as the energetic processes of the cell. On the other hand, free sterols and fatty acids accumulating in yeast cells can cause toxic effects under certain conditions, and maintaining a balance between the biosynthesis and degradation of sterols and triacylglycerols determines cell homeostasis. These processes depend on a proper regulation of inter alia hydrolytic enzymes, including triacylglycerol hydrolases (Grillitsch and Daum, 2011). However, analysis of the sterol content in vegetable oils (Codex Alimentarius, 2013) shows that sterols cannot be inducer of lipase activity, in the light of the results presented in this paper. The total content of sterols in corn oil was as low as $22 \mathrm{~g} / \mathrm{dm}^{3}$ of oil (including a major fraction of $\beta$-sitosterol), peanut oil contains only $3 \mathrm{~g} / \mathrm{dm}^{3}$, while the highes content was found in rice oil $\left(10\right.$ to $\left.31 \mathrm{~g} / \mathrm{dm}^{3}\right)$. These data suggested there was no correlation between the sterol concentration in vegetable oil and the extracellula lipase activity of $Y$. lipolytica KKP 379 , keeping in mind the highest activity was achieved in a medium containing corn oil and the lowest when peanut oil and rice oil were used.

Vegetable oils may contain trace amounts of metals such as iron and copper According to the Codex Alimentarius (2013), refined oils may contain up to 1.5 $\mathrm{mg} \mathrm{Fe} / \mathrm{kg}$ and $0.1 \mathrm{mg} \mathrm{Cu}$, and $5.0 \mathrm{mg} \mathrm{Fe} / \mathrm{kg}$ and $0.4 \mathrm{mg} \mathrm{Cu}$ for virgin oils (Kohlwein and Paltauf, 1984). $Y$. lipolytica lipase activity is positively influenced by the presence of these ions $\left(\mathrm{Ca}^{2+}, \mathrm{Mg}^{2+}\right)$, while others $\left(\mathrm{Zn}^{2+}, \mathrm{Cu}^{2+}\right.$ $\mathrm{Ni}^{2+}$ or $\mathrm{Hg}^{2+}$ ) inhibited lipase activity (Sharma et al., 2001, Pignede et al., 2000; Zhao et al., 2011). The content of these ions in the oils used in this study may be an important factor, which determined whether an individual vegetable oil stimulated microbial lipase production (or not)

\section{CONCLUSIONS}

Vegetable oils are valuable sources of carbon and good inducers of $Y$. lipolytica lipolytic activity. Data from other authors' reports as well as our results suggested that oleic acid was not the only factor determining the high lipolytic activity in medium containing vegetable oil. No relationship was seen between the activity of extracellular lipases synthesized by Y. lipolytica KKP 379 and the percentage of individual fatty acids in the triacylglycerols of the vegetable oils, or their content at positions $s n-1,3$ or $s n-2$ in triglyceride molecule. Yet to be elucidated which factors were responsible for the differences in lipolytic enzyme activity of $Y$. lipolytica cultured in media with various vegetable oils.

Authors proposed several hypothesis, which were shortly described and discussed, but they need further investigations in the field of microbiology, food analysis, biotechnology and biophysics. Further work is required to verify the relationship between intracellular lipid storage and lipase synthesis, the effect of vegetable oils on the synthesis of surfactants and the impact of metal ions in oils on lipase production. The threshold levels of fatty acids, which are essential to initiating gene expression for lipolytic enzymes, and the concentration of free fatty acids, which affects the formation of micelles characterized by the critical micelle concentration (CMC), should be investigated. The possibility of the synthesis of other (than LIP2) lipases, which can be induced by different vegetable oils should be checked as well.

\section{REFERENCES}

AlOUlOU, A., RODRIGUEZ, J.A., PUCCINELli, D., MOUZ, N., LECLAIRE, J., LEBLOND, Y., CARRIÉRE, F. 2007. Purification and biochemical characterization of the LIP2 lipase from Yarrowia lipolytica.

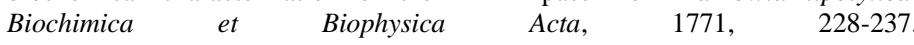
http://dx.doi.org/10.1016/j.bbr.2011.03.031

BARTH, G., GAILLARDIN, C. 1997. Physiology and genetics of the dimorphic fungus Yarrowia lipolytica. FEMS Microbiology Reviews, 19, 219-237. http://dx.doi.org/10.1111/j.1574-6976.1997.tb00299.x

BEOPOULOS, A., CHARDOT, T., NICAUD, J.-M. 2009a. Yarrowia lipolytica: A model and a tool to understand the mechanisms implicated in lipid accumular Biochimie 91 692-696.

http://dx.doi.org/10.1016/j.biochi.2009.02.004

BEOPOULOS, A., CESCUT, J., HADDOUCHE, R., URIBELARREA, J.L., MOLINA-JOUVE, C., NICAUD, J.M. 2009b. Yarrowia lipolytica as a model for bio-oil production. Progress in Lipid Research, 48, 375-387.

http://dx.doi.org/10.1016/j.plipres.2009.08.005

BROCKERHOFF, H., YURKOWSKI, M. 1966. Stereospecific analyses of several vegetable fats. The Journal of Lipid Research, 7, 62-64.

BRYGIDA, A.I.S., AMARAL, P.F.F., COELHO, M.A.Z., GONCALVES L.R.B., 2014. Lipase from Yarrowia lipolytica: Production, characterization and application as an industrial biocatalyst. Journal of Molecular Catalysis B: Enzymatic 101, 148-158. http://dx.doi.org/10.1016/j.molcatb.2013.11.016

BRYŚ, J. 2005. Study on the properties of interesterified mixtures of milkfat with vegetable oils. Doctoral thesis. Warsaw University of Life Sciences, Poland (in Polish).

BURKERT, J.F.M., MAUGERI, F., RODRIGUES, M.I. 2004. Optimization of extracellular lipase production by Geotrichum sp. using factorial design Bioresource Technology, 91, 77-84. http://dx.doi.org/10.1016/S09608524(03)00152-4

CHOE, E., MIN, D.B. 2006. Mechanisms and factors for edible oil oxidation Comprehensive Reviews in Food Science and Food Safety, 5, 169-186. http://dx.doi.org/10.1111/j.1541-4337.2006.00009.x

CODEX ALIMENTARIUS. Codex Standard for named vegetable oils. Codex Stan 210-1999, FAO - Food and Agriculture Organization of the United Nations. Draft endorsed on 15 June 2013

CODEX ALIMENTARIUS. Codex Standard for olive oils and olive pomace oils. Codex Stan 33-1981, FAO - Food and Agriculture Organization of the United Nations. Draft endorsed on 15 June 2013.

CORZO, G., REVAH, S. 1999. Production and characteristics of the lipase from Yarrowia lipolytica 681. Bioresource Technology, 70, 173-180. http://dx.doi.org/10.1016/S0960-8524(99)00024-3

DALMAU, E., MONTESINOS, J.L., LOTTI, M., CASAS, C. 2000. Effect of different carbon sources on lipase production by Candida rugosa. Enzyme and Microbial Technology, 26, 657-663. http://dx.doi.org/10.1016/S01410229(00)00156-3

DARVISHI, F., NAHVI, I., ZARKESH-ESFAHANI, H., MOMENBEIK, F 2009. Effect of plant oils upon lipase and citric acid production in Yarrowia lipolytica yeast. Journal of Biomedicine and Biotechnology, 1-7. Draft endorsed on 20 December 2013. http://dx.doi.org/10.1155/2009/562943

DESFOUGÈRES, T., HADDOUCHE, R., FUDALEJ, F., NEUVÉGLISE, C. NICAUD, J.M. 2009. SOA genes encode proteins controlling lipase expression in response to triacylglycerol utilization in the yeast Yarrowia lipolytica. FEMS Yeast Research, 10, 93-103. http://dx.doi.org/10.1111/j.1567-1364.2009.00590.x DOMÍNGUEZ, A., DEIVE, F.J., SANROMÁN, A., LONGO, M.A. 2003. Effect of lipids and surfactants on extracellular lipase production by Yarrowia lipolytica. Journal of Chemical Technology and Biotechnology, 78, 1166-1170. http://dx.doi.org/10.1002/jctb.922

FABISZEWSKA, A. 2013. Studies on catalytic properties of Yarrowia lipolytica yeast in biotransformations, $\mathrm{PhD}$ thesis, Warsaw University of Life Sciences, Poland (in Polish)

FABISZEWSKA, A.U., STOLARZEWICZ, I.A., ZAMOJSKA, W.M., BIAŁECKA-FLORJAŃCZYK, E. 2014. Carbon source impact on Yarrowia lipolytica KKP 379. Applied Biochemistry and Microbiology, 50, 404-410. 
http://dx.doi.org/10.1134/S000368381404005x

FICKERS, P., NICAUD, J.-M., DESTAIN, J., THONART, P. 2003. Overproduction of lipase by Yarrowia lipolytica mutants. Applied Microbiology and Biotechnology, 63, 136-142. http://dx.doi.org/10.1007/s00253-003-1342-3 FICKERS, P., NICAUD, J.M., GAILLARDIN, C., DESTAIN, J., THONART, P 2004. Carbon and nitrogen sources modulate lipase production in the yeast Yarrowia lipolytica. Journal of Applied Microbiology, 96, 742-749. http://dx.doi.org/10.1111/j.1365-2672.2004.02190.x

FICKERS, P., BENETII, P.H., WACHÉ, Y., MARTY, A., MAUERSBERGER S., SMIT, M.S., NICAUD, J.M. 2005 a. Hydrophobic substrate utilization by the yeast Yarrowia lipolytica, and its potential applications. FEMS Yeast Research, 5, 527-543. http://dx.doi.org/10.1016/j.femsyr.2004.09.004

FICKERS, P., NICAUD, J.M., DESTAIN, J., THONART, P. 2005 b. Involvement of hexokinase Hxk1 in glucose catabolite repression of LIP2 encoding extracellular lipase in the yeast Yarrowia lipolytica. Current Microbiology, 50, 133-137. http://dx.doi.org/10.1007/s00284-004-4401-9

FICKERS, P., MARTY, A., NICAUD, J.M. 2011. The lipases from Yarrowia lipolytica: genetics, production, regulation, biochemical characterization and biotechnological applications. Biotechnology Advances, 29, 632-644. http://dx.doi.org/10.1016/j.biotechadv.2011.04.005

GORDILLO, M.A., OBRADOS, N., MONTESINOS, J.L., VALERO, F., LAFUENTE, J., SOLÁ, C. 1995. Stability studies and effect of the initial oleic acid concentration on lipase production by Candida rugosa. Applied Microbiology and Biotechnology, 43, 38-41. http://dx.doi.org/10.1007/BF00170620

GRILLITSCH, K., DAUM, G. 2011. Triacylglicerol lipases of the yeast. Frontiers of Biology, 6, 219-230. http://dx.doi.org/10.1007/s11515-011-1142-6 GUERZONI, M.E., LANCIOTTI, R., VANNINI, L., GALGANO, F., FAVATI, F. GARDINI, F., SUZZI, G. 2001. Variability of the lipolytic activity in Yarrowia lipolytica and its dependence on environmental conditions. International Journal of Food Microbiology, 69, 79-89. http://dx.doi.org/10.1016/S0168 1605(01)00575-X

GURVITZ, A., ROTTENSTEINER, H. 2006. The biochemistry of oleate induction: transcriptional upregulation and peroxisome proliferation. Biochimica et Biophysica Acta, 1763, 1392-1402. http://dx.doi.org/10.1016/j.bbamcr.2006.07.011

HADEBAL, W. 1991. Production of lipase by Yarrowia lipolytica: I. Lipases from yeasts (review). Acta Biotechnologica, 11, 159-167. http://dx.doi.org/10.1002/abio.370110217

HSU, K.H., LEE, G.C., SHAW, J.F. 2008. Promoter analysis and differentia expression of the Candida rugosa lipase gene family in response to culture conditions. Journal of Agriculture and Food Chemistry, 56, 1992-1998. http://dx.doi.org/10.1021/jf073076o

JUNG, J.-H., YOON, D.-H., KANG, P., LEE, W.K., EUM, H., HA, H.-J. 2013 CAL-B catalyzed desymmetrization of 3-alkylglutarate: "olefin effect" and asymmetric synthesis of pregabalin. Organic and Biomolecular Chemistry, 11, 3635-3641. http://dx.doi.org/10.1039/c3ob40311d

KEBABCI, Ö., CÍHANGÍR, N. 2012. Comparison of three Yarrowia lipolytica strains for lipase production: NBRC 1658, IFO 1195, and a local strain. Turkish Journal of Biology, 36, 15-24. http://dx.doi.org/10.3906/biy-1102-10

KOHLWEIN, S.D., PALTAUF, F. 1984. Uptake of fatty acids by the yeasts, Saccharomyces uvarum and Saccharomycopsis lipolytica. Biochimica Biophysica Acta (BBA) - Lipids Lipid Metabolism, 792, 310-317. http://dx.doi.org/10.1016/0005-2760(84)90198-X

KAPTUROWSKA, A.U., STOLARZEWICZ, I.A., KRZYCZKOWSKA， J. BIAŁECKA-FLORJAŃCZYK, E. 2012. Studies on lipolytic activity of sonicated enzymes from Yarrowia lipolytica. Ultrasonics Sonochemistry, 19, 186-191. http://dx.doi.org/10.1016/j.ultsonch.2011.06.015

KRZYCZKOWSKA, J., STOLARZEWICZ, I., BIAŁECKA-FLORJAŃCZYK E. 2009. Spektrofotometryczna metoda pomiaru aktywności lipaz w reakcji hydrolizy laurynianu p-nitrofenylu, Monograph: Wielokierunkowość Badań w Rolnictwie i Leśnictwie, 2, 665-671 (in Polish).

MONTESINOS, J.L., OBRADORS, N., GORDILLO, M.A., VALERO, F. LAFUENTE, J., SOLÁ, C. 1996. Effect of nitrogen sources in batch and continuous cultures to lipase production by Candida rugosa. Applied $\begin{array}{llll}\text { Biochemistry and } \quad \text { Biotechnology, } & \text { 25-37. }\end{array}$ http://dx.doi.org/10.1007/BF02787855

NAJJAR, A., ROBERT, S., GUÉRIN, C., VIOLET-ASTHER, M., CARRIÈRE, F. 2011. Quantitive study of lipase secretion, extracellular lipolysis, and lipid storage in yeast Yarrowia lipolytica grown in the presence of olive oil: analogies with lipolysis in humans. Applied Microbiology and Biotechnology, 89, 1947 1962. http://dx.doi.org/10.1007/s00253-010-2993-5

PAPANIKOLAOU, S., CHEVALOT, J., KOMAITIS, M., AGGELIS, G. MARC, I. 2001. Kinetic profile of the cellular lipid composition in an oleaginous Yarrowia lipolytica capable of producing a cocoa-butter substitute from industrial fats. Antonie van Leeuwenhoek, 80, 215-224. http://dx.doi.org/10.1023/A:1013083211405

PAPANIKOLAOU, S., CHEVALOT, J., KOMAITIS, M., MARC, I. 2002. Single cell oil production by Yarrowia lipolytica growing on an industria derivative of animal fat in batch cultures. Applied Microbiology and Biotechnology, 58, 308-312.

http://dx.doi.org/10.1007/s00253-001-0897-0

PAPANIKOLAOU, S., AGGELIS, G. 2003. Selective uptake of fatty acids by the yeast Yarrowia lipolytica. European Journal of Lipid Science and Technology, 105, 651-655. http://dx.doi.org/10.1002/ejlt.200300858

PEREIRA-MEIRELLES, F.V., ROCHA-LEÃO, M.H.M., SANT'ANNA Jr, G.L. 2000. Lipase location in Yarrowia lipolytica cells. Biotechnology Letters, 22, 71 75. http://dx.doi.org/10.1023/A:1005672731818

PETERS, I.I, NELSON, F.E. 1948 a. Factors influencing the production of lipase by Mycotorula lipolytica. Journal of Bacteriology, 55, 581-591.

PETERS, I.I, NELSON, F.E. 1948 b. Preliminary characterization of the lipase of Mycotorula lipolytica. Journal of Bacteriology, 55, 593-600.

PIGNÈDE, G., WANG, H., FUDALEJ, F., GAILLARDIN, C., SEMAN, M. NICAUD, J.M. 2000. Characterization of an extracellular lipase encoded by $L I P 2$ in Yarrowia lipolytica. Journal of Bacteriology, 182, 2802-2810. http://dx.doi.org/10.1128/JB.182.10.2802-2810.2000

PRZYBYLSKI, R. 2005 a. Flax Oil and High Linolenic Oils. 281-301. In: Shahidi F (ed) (2005) Bailey's Industrial Oil and Fat Products. USA: John Wiley and Sons, Inc.

PRZYBYLSKI, R., MAG, T., ESKIN, N.A.M., MCDONALD, B.E. 2005 b Canola Oil. 61-121. In: Shahidi F (ed) (2005) Bailey's Industrial Oil and Fat Products. USA: John Wiley and Sons, Inc.

REIS, P., HOLMBERG, K., WATZKE, H., LESER, M.E., MILLER, R. 2009 Lipases at interfaces: A review. Advances in Colloid and Interface Science, 147148, 237-250. http://dx.doi.org/10.1016/j.cis.2008.06.00

ROGALSKA, E., RANSAC, S., CARRIERE, F., VERGER, R. 2000. Stereoselective hydrolysis of glycerides by lipases. 47-59, In: Armand CB, De Vriese S.(ed) (2000) Fat Digestion and Absorption, USA: AOCS Press

SHARMA, R., CHISTI, Y., BANERJEE, U.Ch. 2001. Production, purification, characterization and application of lipases. Biotechnology Advances, 19, 627-662. http://dx.doi.org/10.1016/S0734-9750(01)00086-6

SPENCER, J.F., RAGOUT DE SPENCER, A.L., LALUCE, C. 2002. Nonconventional yeasts. Applied Microbiology and Biotechnology, 58, 147-156. http://dx.doi.org/10.1007/s00253-001-0834-2

WANG, D., XU, Y., SHAN, T. 2008. Effects of oils and oil-related substrates on the synthetic activity of membrane-bound lipase from Rhizupus chinesis and optimization of the lipase fermentation media. Biochemical Engineering Journal, 41, 30-37. http://dx.doi.org/10.1016/j.bej.2008.03.003

WEI, D., ZHANG, L., SONG, Q. 2004. Studies on a novel carbon source and cosolvent for lipase production by Candida rugosa. Journal of Industrial Microbiology and Biotechnology, 31, 133-136. http://dx.doi.org/10.1007/s10295004-0126-9

VOGEL, A.I., FURNISS, B.S., TATCHELL, A.R., HANNAFORD, A.J., SMITH, P.W.G. (ed.) 1996. Vogel's Textbook of Practical Organic Chemistry (5th Edition), USA: Prentice Hall.

ZHAO, H., ZHENG, L., WANG, X., LIU, Y., XU, L., YAN, Y. 2011. Cloning, expression and characterization of new lipases from Yarrowia lipolytica. Biotechnology Letters, 33, 2445-2452. http://dx.doi.org/10.1007/s10529-011 0711-8 